\title{
ON VIOLENCE
}




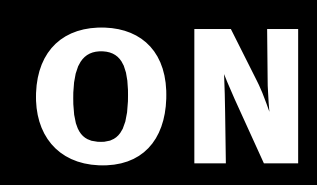

DUKE UNIVERSITY PRESS DURHAM AND LONDON 2007 


\section{VIOLENCE}

Edited by Bruce B. Lawrence and Aisha Karim 
(C) 2007 Duke University Press

All rights reserved. Printed in the United States of America on acid-free paper $\infty$ Designed by Amy Ruth Buchanan.

Typeset in Minion and Meta by Keystone Typesetting, Inc. Library of Congress Cataloging-in-Publication data appear on the last printed page of this book.

Duke University Press gratefully acknowledges the support of the Harry Frank Guggenheim Foundation, which provided funds toward permission costs of this book. 
FOR JAMES HESTER

AND KAREN COLVARD,

pillars and pioneers

of research on violence 
